Applied Field Research Article

\title{
Humusica 2, Article 14: Anthropogenic soils and humus systems, comparing classification systems ${ }^{\text {hै }}$
}

\author{
Augusto Zanella ${ }^{\mathrm{a}, *}$, Peter Schad ${ }^{\mathrm{b}}$, John Galbraith ${ }^{\mathrm{c}}$, Jean-François Ponge ${ }^{\mathrm{d}}$ \\ ${ }^{\text {a }}$ University of Padova, Italy \\ b Technische Universität München, Germany \\ c Crop and Soil Environmental Sciences, Virginia Tech, United States \\ d Muséum National d'Histoire Naturelle, Paris France
}

\section{A R T I C L E I N F O}

\section{Keywords:}

Humus

Humusica

Anthropogenic soils

Techno soils

Agro humus

Techno humus

Urban soils

\begin{abstract}
A B S T R A C T
The aim of this article is to present a sort of state of the art from a soil classification point of view. How far are soils from their original natural state? A few years ago, the two most important soil classification systems added a classification of anthropogenic soils. Even so, the concept of anthropogenic soil differs slightly in the two systems, it is easy to recognize these soils all around us, in both urban and agricultural contexts. After presenting the main types of anthropogenic soil, using the WRB or Soil Taxonomy characteristics, we will focus on anthropogenic humipedons, presenting a table where they are subdivided into two new units called Agro (natural topsoils used for agricultural purposes) and Techno (human-made humus systems). This allows to conceptually compare soil and humipedon classifications, and prepares the field for further investigations on Agro (Humusica 2, art. 15) and Techno (Humusica 2, art. 16) humipedons.
\end{abstract}

\section{Introduction}

The Anthropocene is a proposed epoch that begins when human activities started to have a significant global impact on Earth's geology and ecosystems.

In January 2015, 26 of the 38 members of the International Anthropocene Working Group published a paper suggesting that the Trinity nuclear test on July 16, 1945, was the starting point of the proposed new epoch. However, a significant minority supports one of several alternative dates. Lewis and Maslin (2015) suggested either 1610 or 1964 could be the beginning of Anthropocene. Other scholars point to the diachronous character of the physical strata of the Anthropocene, arguing that onset and impact are spread out over time, not reducible to a single instant or date of start.

The Anthropocene Working Group met in Oslo in April 2016 to consolidate evidence supporting the argument that the Anthropocene is a true geologic epoch. Evidence was evaluated and the group voted to recommend Anthropocene as the new geological age in August 2016.

From: https://en.wikipedia.org/wiki/Anthropocene

\section{Anthropogenic soils}

Humans have modified almost everything on planet Earth. They used the soil for producing food or extracting materials for industrial purposes (Bender et al., 2016; Certini and Scalenghe, 2011; Osman, 2014; Richter et al., 2015). Humans manipulated every type of ecosystem, treating plants and soils as they were infinite resources. World Reference Base for Soils Resources (IUSS Working Group WRB, 2015) and USDA Soil Taxonomy (Soil Survey Staff, 2014) classifications evolved relatively separately, diverged for a long time and proposed similar references only for some main soil units at large scale. Histosols, Cryosols, Podzols, Vertisols, and Andosols in WRB have some similarities to Histosols, Gelisols, Spodosols, Vertisols, and Andisols in ST. Anthropogenic soils have also been considered in WRB and ST, and their classification is less diverse than that of many other soils. In addition, artificial soils are often the result of human activities affecting only the humipedon and, in this perspective, correspond more to anthropogenic humus systems and forms than other soils. For these reasons, we start the presentation of these humus systems with their main characteristics identified by soil experts, with the aim to obtain a more shareable definition which could open the door for cooperation, at least for these soils, between soil and humus specialists.

\section{WRB concept of anthropogenic soils}

The IUSS Group (IUSS Working Group WRB, 2015) placed

\footnotetext{
Background music while reading: Artifacts - That's Them: https://www.youtube.com/watch?v=ct3s_9TFaLw.

* Corresponding author.

E-mail addresses: augusto.zanella@unipd.it (A. Zanella), schad@wzw.tum.de (P. Schad), john.galbraith@vt.edu (J. Galbraith), ponge@mnhn.fr (J.-F. Ponge).
} 
Table 1

Conceptual and practical differences between Agro and Techno humus systems.

\begin{tabular}{|c|c|c|c|}
\hline $\begin{array}{l}\text { HUMUS } \\
\text { SYSTEM }\end{array}$ & DESCRIPTION & DIAGNOSTIC CHARACTERS & MANAGEMENT \\
\hline AGRO & $\begin{array}{l}\text { Recognizable natural humus system, more or less } \\
\text { modified by man or under prominent man influence. } \\
\text { It is still possible to assign an Agro humus profile to } \\
\text { an analogue, functionally similar, natural reference. } \\
\text { Agricultural humus systems or less artificial urban } \\
\text { humus systems. }\end{array}$ & $\begin{array}{l}\text { Humus system laying on mineral soil horizons. At } \\
\text { least one humus horizon (organic or organic-mineral) } \\
\text { recognizable and amenable to a natural functionally } \\
\text { similar humus horizon. Tillage profile or managed } \\
\text { dump of organic remains. }\end{array}$ & $\begin{array}{l}\text { Agricultural fields, market gardens, kitchen } \\
\text { gardens, not strongly altered urban humus systems } \\
\text { (under trees or shrubby areas), }\end{array}$ \\
\hline \multirow[t]{3}{*}{ TECHNO } & $\begin{array}{l}\text { A) Manure humus systems, man-made humus } \\
\text { systems with soil: compost or mulch, other artificial } \\
\text { organic or mineral-organic mixtures. }\end{array}$ & $\begin{array}{l}\text { A) Man made humus systems wanting to mimic } \\
\text { natural systems, with natural materials and soil; } \\
\text { humus horizons are generally recognizable even if } \\
\text { animal and microbial foodwebs may be poorer or not } \\
\text { the same as in natural processes. }\end{array}$ & $\begin{array}{l}\text { A) Used to restore strongly exploited soils, } \\
\text { increase their content in organic matter and } \\
\text { biodiversity }\end{array}$ \\
\hline & $\begin{array}{l}\text { B) Soil-free humus systems, nutriculture, hydroponic } \\
\text { systems without soil }\end{array}$ & $\begin{array}{l}\text { B) Absence of soil, humus systems without organic or } \\
\text { organic-mineral soil horizons; the use of inert medium } \\
\text { (gravel, sand, sawdust, rockwool, cococoir, peat, } \\
\text { vermiculite, perlite, pumice, rice hulls, other soil-free } \\
\text { mixtures) is very common but soil formation/ } \\
\text { structuration is always avoided }\end{array}$ & $\begin{array}{l}\text { B) Greenhouse production, sunlight and artificial } \\
\text { lighting, verticalisation of vegetable and fruit } \\
\text { production, possible even without soil, use of } \\
\text { treated wastewater... }\end{array}$ \\
\hline & $\begin{array}{l}\text { C) Dump humus systems, more or less uncontrolled } \\
\text { sewage sludge, toxic waste, landfill waste, colonized } \\
\text { masonry waste, other topsoils abandoned to } \\
\text { recycling of wastes and biodegraded materials }\end{array}$ & $\begin{array}{l}\text { C) Material under decomposition, but diagnostic } \\
\text { horizon so rich in artefacts or waste materials or } \\
\text { technic material that it is impossible to recognize a } \\
\text { natural humus horizon or system. }\end{array}$ & $\begin{array}{l}\text { C) Landfills, waste heaps, industrial waste, very } \\
\text { altered urban humus systems }\end{array}$ \\
\hline
\end{tabular}

anthropogenic soils into two Reference Soil Groups: Anthrosols and Technosols.

Anthrosols are defined by diagnostic horizons starting at the soil surface with a thickness of at least $50 \mathrm{~cm}$. These horizons are either the result of the addition of material (Irragric, Hortic, Plaggic, Pretic, Terric Anthrosols) or of the in-situ management under waterlogging (Hydragric Anthrosols). With the exception of the Hydragric ones, Anthrosols cover small areas. Many Anthrosols have been formed during hundreds or thousands of years. Irragric and Hydragric Anthrosols are usually still under agriculture, but many of the others are not. The present-day intensive agricultural use (ploughing, fertilization, agrochemicals) does not lead to the formation of Anthrosols.

Here down a very simplified presentation of 6 groups of WRB Anthrosols:

1. Plaggic Anthrosols - with a plaggic horizon: dark, at least moderate content of organic matter, sandy or loamy; resulting from repeated application of sods (which consist of grassy, herbaceous or dwarfshrub vegetation, its root mats and soil material sticking to them). and excrements.

2. Hortic Anthrosols - with a hortic horizon: dark, high content of organic matter and $\mathrm{P}$, high animal activity, high base saturation; resulting from long-term cultivation, fertilization and application of organic residues

3. Terric Anthrosols - with a terric horizon: showing a colour related to the source material, high base saturation; resulting from the addition of mineral material (with or without organic residues) and deep cultivation.

4. Pretic Anthrosols - with a pretic horizon: dark, high content of organic matter and $\mathrm{P}$, low animal activity, high contents of exchangeable $\mathrm{Ca}$ and $\mathrm{Mg}$, with remnants of charcoal and/or artefacts, including Amazonian Dark Earths (terra preta de indio).

5. Irragric Anthrosols - with an irragric horizon: uniformly structured, at least moderate content of organic matter, high animal activity; gradually built up by sediment-rich irrigation water.

6. Hydrargic Anthrosols - with an anthraquic horizon and an underlying hydragric horizon. Anthraquic horizon: the layer comprising the puddled layer and the plough pan, both showing a reduced matrix and oxidized root channels. Hydragric horizon: the layer below the anthraquic horizon showing redoximorphic features and/ or an accumulation of $\mathrm{Fe}$ and/or Mn.
In WRB (IUSS Working Group WRB, 2015), cities, roads, mines, refuse dumps, oil spills, coal fly ash deposits and the like are included in Technosols with a lot of principal and supplementary qualifiers. Two technogenic diagnostic materials (predominantly understood as parent materials) are especially described:

- Artefacts: created, substantially modified or brought to the surface by humans; no subsequent substantial change of chemical or mineralogical properties.

- Technic hard material: consolidated and relatively continuous material resulting from an industrial process.

WRB provides the following qualifiers for soils that are normally not Technosols:

- Transportic: human-transported natural material;

- Relocatic: in-situ remodelling;

- Densic: compaction.

\section{Soil taxonomy concept of anthropogenic soils}

USDA Soil Taxonomy (Soil Survey Staff, 2014) proposes an Anthropic Epipedon which "consists of mineral soil material that shows evidence of the purposeful alteration of soil properties or of earth-surface features by human activity. The field evidence of alteration is significant and excludes agricultural practices such as shallow ploughing or addition of amendments, such as lime or fertilizer" (Soil Survey Staff, 2014; Staff Soil Survey, 2015).

Diagnostic characters for anthropogenic (Human-Altered and Human-Transported, HAHT) soils that possibly occur in anthropic epipedons are given in the manual as well as a list of diagnostic surface and subsurface horizons that may be present (Soil Survey Staff, 2014). There are "Constructional and Destructional Anthropogenic Landforms", "Constructional and Destructional Microfeatures", "Artifacts", "Human-Altered and Human-Transported Materials", and "Manufactured Layers and Contacts". All of these human "artificial constructions" were made on and in the soil. They do not correspond directly to the WRB Technosols or Anthrosols because they are not recognized at the order level and can occur in any soil order.

Soil Taxonomy uses subgroup adjectives for allocation of HAHT soil. These taxa (not adjectives or modifiers but actual classes) characterize "distinct groups of human-altered and human-transported extragrade 

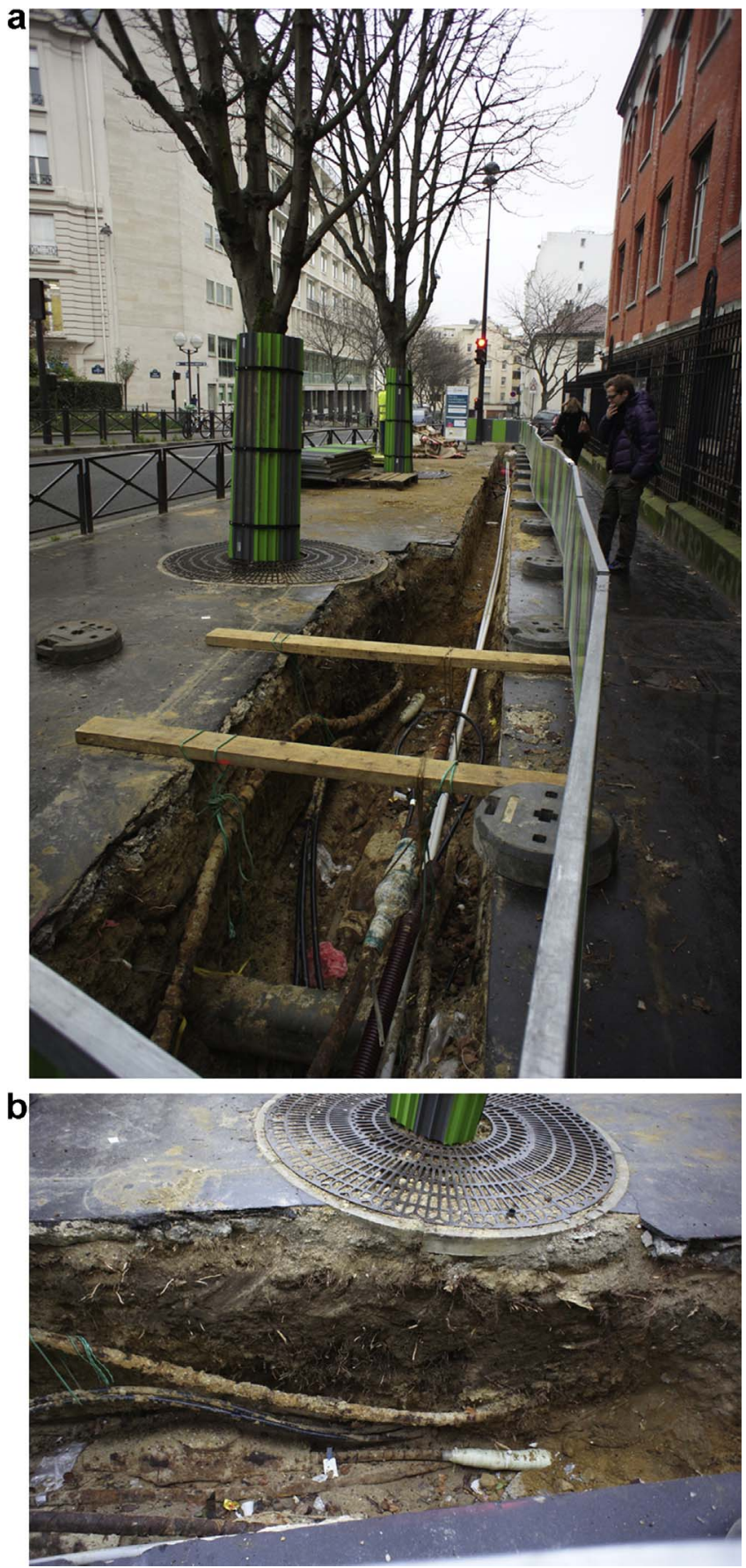

soils, since they do not represent an intergrade to any other named taxon (Soil Survey Staff, 1999). They are listed in order of interpretative significance as a guide, but the significance and order may change slightly depending on the great group in which they are recognized:

1. Anthraquic - current or former ponded surface due to flood irrigation, often with puddled or compacted horizons to hold water near the surface. Found most often in rice paddies and aquaculture areas.

2. Anthrodensic - have a constructed densic contact due to human activity. Found most often in reclaimed mine lands and building or transportation sites.

3. Anthropic - have an anthropic epipedon (newly redefined). Found in many areas associated with sustained human habitation.

4. Plaggic - have a plaggen epipedon $(50 \mathrm{~cm}$ or more of plaggen
Fig. 1. Urban soil in Paris. a) Dugout opened for undergrounding electric and phone line under sidewalk and street trees; b) topsoil (humipedon) under the first tree of a. Classification:

1. IUSS Working Group WRB (2015): Ekranic Technosol. Technosols (from Greek technikos, skilfully made) combine soils whose properties and pedogenesis are dominated by their technical origin. Technosoils contain a significant amount of artefacts (something in the soil recognizably made or strongly altered by humans or extracted from greater depths) are sealed by technic hard material (hard material created by humans, having properties unlike natural rock) or contain a geomembrane. Technosoils include soils from wastes (landfills, sludge, cinders, mine spoils and ashes), pavements with their underlying unconsolidated materials, soils with geomembranes and constructed soils. Technosols are often referred to as Urban or Mine soils. Ekranic (ek) (from French écran, shield): having technic hard material starting $5 \mathrm{~cm}$ from the soil surface (in Technosols only). Transportic (human-transported natural material), Relocatic (in-situ remodelling) and Densic (compaction) qualifiers may be used too.

2. Soil Survey Staff (2014): assuming an ustic soil moisture regime for Paris and a relatively neutral $\mathrm{pH}$ as is typical in urban areas, this soil can be classified as a Fine-loamy, spolic, mixed, mesic family of Anthropic Anthroportic Haplustepts. Spolic class of Human-Altered and Human-Transported Material is employed in presence of an A horizon or layer $50 \mathrm{~cm}$ (or more) thick of human-transported material.

3. Humusica classification: A young street tree ( $8-10$ years) is generally planted with its roots in a volume of fertilized soil. In Fig. 1b, this predisposed soil is noticeable under the tree stem. Very poor in pedofauna, the humipedon shows a rather massive structure and may be classified as massive Agro humus form (refer to Humusica 2, article 15 for a detailed classification of Agro systems). Avoiding to cover the soil surface with coarse artificial material, would allow fresh litter to periodically feed this humipedon, which may easily evolve towards a more active biomacro- or biomesostructured Mull system. In its present-day form, this humipedon cannot be classified as Techno humus system. Only the original, fertilized A horizon used as bed for the trees plantation may be assigned to a Techno humus system (refer to Humusica 2 article 16 for a detailed description of Techno humus systems). Techno humus system alike composts or mulch may be applied to stressed soils in order to restore their lost biological activity.

(Photographs: A. Zanella).

material). Found mostly in northwest Europe.

5. Haploplaggic - have $25-49 \mathrm{~cm}$ of plaggen materials. Found mostly in northwest Europe

6. Anthroportic- parent material was transported by humans. Found worldwide

7. Anthraltic - parent material was altered in place by humans. Found mainly in deeply and intensively-cultivated areas.

Curious readers my refer to Charzyński et al. (2017) for a meticulously described WRB and ST urban soil classification.

\section{Proposed use of some WRB and ST qualifiers in the classification of humus systems}

2 of the 7 ST subgroups may be "compared" to WRB Anthrosols:

ST 4 (Plaggic) to WRB 1 (Plaggic); ST 1 (Anthraquic) to WRB 6 (Hydrargic).

Soils with ST 3 (Anthropic) may be "compared" either to the Hortic, Terric or Pretic Anthrosols (WRB 2, 3, and 4) or to the Technosols with artefacts (WRB 7).

Soils with ST 2 (Anthrodensic) may have the Densic qualifier in WRB, soils with ST 6 (Anthroportic) the Transportic qualifier. ST 7 (Anthraltic) are mixed in-situ and not transported to another location by humans: the Relocatic qualifier cannot be used with them.

The others have no correspondence in the other system, respectively.

\section{Anthropogenic agro and techno humus systems}

Soil scientists are asked to estimate the difference between "good" or "bad", fertile or unproductive, healthy or polluted, "stressed", poorly bio-diverse, or "radioactive" soils. From this point of view, a useful goal of a modern classification of anthropogenic soils might be to document increasing human pressure, better if spread along a gradual passage (in order to fix each intermediate level of modification) from good to bad soils or from natural and relatively well equilibrated or slightly polluted 
soils to sub-natural or totally transformed unnatural soils.

Our Histic, Aqueous, Terrestrial and Para humus systems can be considered as humipedons approaching "natural-not strongly transformed humipedons"; Agro and Techno humus systems could be understood as "soils transformed or simplified for producing food" (Agro and Techno Manure and Soil-free) or "artificial new substrates deserving other purposes, like storing more or less artificial substances or wastes (Techno Dump), or trying to imitate natural soils using artefacts (polystyrene foam, glass, porous artificial materials, plastics...) or plant remains" (Techno Manure and Soil-free). Description, main diagnostic characters and dynamic considerations are reported in Table 1.

Some relationships exist between Agro or Techno humus systems and corresponding WRB Anthrosols and ST HAHT soils. An Hortic WRB group certainly corresponds to a Biomacro Agromull humus system, for instance. However, to fusion these classifications in a single reference is still impossible and probably not necessary.

\section{Example of anthropogenic urban topsoil profile}

The soil represented in Fig. 1a and b is certainly an Anthropogenic topsoil. Photographs were taken in Paris, along a public way. A dugout was opened for undergrounding electric and phone line under sidewalk and street trees (Fig. 1a). On Fig. 1b, by discovering the soil under the first tree of Fig. 1a, it is easy to notice that:

1. Organic topsoil horizons are absent; the soil got instead a hard and artificial cover made of coarse and bitumen;

2. Comparing the topsoil horizons just under the tree stem with the ones on the right and on the left sides of the photograph, we see that the under the tree they are richer in roots and organic matter (dark);

3. The soil looks relatively compact and poor in meso- and macrofauna (no or few natural biological aggregates; refer to Humusica 1, articles 4 and 8 for detailed descriptions of natural soil horizons and aggregates). This anthropogenic humipedon corresponds to a biologically poor Mull nearing a massive Moder humus system. It is classified as massive Agro Mull system (refer to Humusica 2, article 15 for a detailed classification of Agro humus systems);
4. It is possible to revitalize this type of soil by feeding it with the naturally produced tree litter and eventually by inoculating indigenous anecic and endogeic earthworms. We suggest to remove the impermeable cover of part of the sidewalk on a strip between the tree stems, and to allow the tree litter to lay on the soil of the strip. The humipedon will naturally become a more active Mull system, which may support related punctual or linear urban soil-tree ecosystems.

\section{References}

Bender, S.F., Wagg, C., van der Heijden, M.G.A., 2016. An Underground Revolution: Biodiversity and Soil Ecological Engineering for Agricultural Sustainability. Trends Ecol. Evol. http://dx.doi.org/10.1016/j.tree.2016.02.016.

Certini, G., Scalenghe, R., 2011. Anthropogenic soils are the golden spikes for the Anthropocene. Holocene 21 (8), 1269-1274. http://dx.doi.org/10.1177/ 0959683611408454.

Charzyński, P., Galbraith, J.M., Kabała, C., Kühn, D., Prokofeva, T.V., V.I., V. (2017) Classification of urban soils. In: L. Maxine J., K.-H. John Kim, M. Jean Louis, B., Wolfgang, C., Przemyslaw, R. Ahaw K., IUSS Working Group SUITMA, 2017 (Eds.), Soils within Cities. Global approaches to their sustainable management - composition, properties, and functions of soils of the urban environment. GeoEcology essay, ISBN 978-3-510-65411-6.

IUSS Working Group WRB, 2015. World Reference Base for Soil Resources 2014. Update 2015 International Soil Classification System for Naming Soils and Creating Legends for Soil Maps. World Soil Resources Reports No . 106. Food and Agriculture Organization of the United Nations, Rome, Italy.

Lewis, S.L., Maslin, M.A., 2015. Defining the anthropocene. Nature 519 (7542), 171-180. http://dx.doi.org/10.1038/nature14258. Retrieved from.

Osman, K.T., 2014. Soil degradation, conservation and remediation. Soil Degrad. Conserv. Remediat. 9789400775. http://dx.doi.org/10.1007/978-94-007-7590-9.

deB Richter, D., Bacon, A.R., Brecheisen, Z., Mobley, M.L., 2015. Soil in the anthropocene. IOP Conf. Ser.: Earth Environ. Sci. 25, 12010. http://dx.doi.org/10.1088/17551315/25/1/012010.

Soil Survey Staff, 2014. Keys to soil taxonomy by soil survey staff, 12th edition. Soil Conservation Service, vol. 12 United States Department of Agriculture, Natural Resources Conservation Service, Washington, DC Retrieved from. http://www.nrcs. usda.gov/Internet/FSE_DOCUMENTS/nrcs142p2_051546.pdf.

Staff Soil Survey, 2015. Iluustrated Guide to Soil Taxonomy, Version 2. U.S. Department of Agriculture, Natural Resources Conservation Service, National Soil Survey Center, Lincoln, Nebraska, USA Retrieved from. https://www.google.it/search?q= USDA + Soil + Taxonomy $+($ ST $)+$ proposes + an + Anthropic + Epipedon\&oq $=$ USDA + Soil + Taxonomy $+($ ST $)+$ proposes + an + Anthropic + Epipedon\&aqs + chrome..69i57.1518j0j7\&sourceid $=$ chrome\&ie $=$ UTF-8 . 